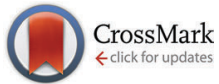

Cite this: New J. Chem., 2016, 40,7421

Received (in Montpellier, France) 25th April 2016.

Accepted 9th June 2016

DOI: 10.1039/c6nj01311b

www.rsc.org/njc

\section{Understanding multivalent effects in glycosidase inhibition using $C$-glycoside click clusters as molecular probes $\dagger$}

\author{
Fabien Stauffert, ${ }^{a}$ Anne Bodlenner, ${ }^{a}$ Thi Minh Nguyet Trinh, ${ }^{b}$ \\ M. Isabel García-Moreno, ${ }^{c}$ Carmen Ortiz Mellet, ${ }^{c}$ Jean-François Nierengarten ${ }^{\star b}$ \\ and Philippe Compain ${ }^{\star a}$
}

\begin{abstract}
The synthesis of the first examples of multivalent $C$-glycosides based on $C_{60}$-fullerene or $\beta$-cyclodextrin cores by way of $\mathrm{Cu}(\mathrm{I})$-catalyzed azide-alkyne cycloadditions is reported. These compounds were designed as molecular probes to understand the mechanisms underlying the outstanding multivalent effects observed in glycosidase inhibition. The inhibition results obtained support a multivalent-binding model based on two scenarios both involving nonspecific interactions and varying by the presence or the absence of active site specific interactions. The magnitude of the multivalent effect obtained depends on the identity of the glycosidase involved and more specifically on the accessibility of its catalytic active site. Large inhibitory multivalent effects can be obtained when both glycosidase active sites and non-catalytic sites at the protein surface are involved in binding events. On the other hand, nonspecific interactions alone are not sufficient to achieve relative affinity enhancements exceeding a simple statistical effect (i.e., a relative inhibition potency not better than one on a valence-corrected basis).
\end{abstract}

\section{Introduction}

The recent discovery of multivalent glycosidase inhibitors showing outstanding binding enhancements up to five orders of magnitude over the corresponding monovalent ligands challenges and stimulates the imagination of (bio)chemists. ${ }^{1-4}$ First, because these enzymes, which powerfully catalyse glycosidic cleavage in carbohydrates and glycoconjugates, do not exhibit the typical structural features required for multivalent design. Glycosidases indeed display generally a single, buried catalytic site ${ }^{5}$ and bind to their monovalent substrates with high affinity and selectivity. The main approach to reversible glycosidase inhibitors has been consequently based on natural substrate mimetics, such as iminosugars in which the endocyclic oxygen atom of the parent glycosides is replaced by a nitrogen atom. ${ }^{6,7}$ The high affinity of iminosugars for

\footnotetext{
${ }^{a}$ Laboratoire de Synthèse Organique et Molécules Bioactives (SYBIO), Université de Strasbourg/CNRS (UMR 7509), Ecole Européenne de Chimie, Polymères et Matériaux (ECPM), 25 rue Becquerel, 67087 Strasbourg Cedex 2, France. E-mail: philippe.compain@unistra.fr

${ }^{b}$ Laboratoire de Chimie des Matériaux Moléculaires, Université de Strasbourg et CNRS (UMR 7509), Ecole Européenne de Chimie, Polymères et Matériaux, 25 rue Becquerel, 67087 Strasbourg Cedex 2, France. E-mail: nierengarten@unistra.fr ${ }^{c}$ Departamento de Quimica Orgánica, Facultad de Quimica, Universidad de Sevilla, Profesor García González 1, E-41012, Sevilla, Spain

$\dagger$ Electronic supplementary information (ESI) available. See DOI: 10.1039/c6nj01311b
}

glycosidases is commonly explained by their ability to become protonated in biological medium and to form ammonium cations that interact strongly with a nucleophilic catalytic residue, commonly a carboxylate, in the enzyme active site. ${ }^{8}$ In sharp contrast, lectins, an important class of proteins playing numerous roles in biological recognition phenomena, appear to be ideal candidates for multivalent design as they usually display accessible, multiple carbohydrate-binding pockets. ${ }^{9}$ In such systems, multivalent interactions are used by Nature as a method to increase affinity and modulate selectivity since monovalent carbohydrate ligands typically bind only weakly to lectin receptors. The bridging of several adjacent binding sites by multidentate ligands, i.e. the so-called chelate effect, is indeed at the basis of the largest multivalent effects known to date. ${ }^{9,10}$ For proteins with one binding site, as anticipated for most enzymes, the statistical rebinding effect, which is due to high local ligand concentration, is believed to be one of the major binding modes at play. ${ }^{10} f$ In combination with chelation or non-chelation mechanisms, additional aggregation phenomena have also to be considered, further complicating the rationale behind the observed multivalent effects. It is worth noting that systems that do not allow chelation mechanisms typically show moderate multivalent effects and require ligands with very high valency ( $>c a$. 100-150) to reach significant affinity enhancements. ${ }^{10 f}$ Considering these points, how to explain that the multivalent effects observed in glycosidase 
inhibition with neoglycoclusters displaying up to 36 iminosugar ligands ${ }^{2,3}$ rival those encountered for carbohydrate-lectin interactions? To answer this fundamental question, the molecular basis of the rather counter-intuitive inhibitory multivalent effect has been explored independently by several groups using different strategies ${ }^{3,11,12 a, 13,14}$ and complementary techniques including isothermal titration calorimetry, ${ }^{12 a}$ mass spectrometry, ${ }^{3}$ electron microscopy imaging ${ }^{3}$ and atomic force microscopy. ${ }^{11}$ Beyond fundamental interest in understanding these new phenomena, these studies are also stimulated by the therapeutic relevance of glycosidase inhibitors ${ }^{6,7,15}$ and by the first promising applications of the multivalent effect to cellular glycosidases for correcting protein folding defects. ${ }^{16}$ Recently, the dual lectin- and glycosidase binding abilities of designed $\mathrm{C}_{60}$-based $\mathrm{sp}^{2}$-iminosugar clusters ${ }^{17}$ were exploited to probe the involvement of non-catalytic sites and active site interactions in multivalent binding events. Competitive lectin-glycosidase assays, which were performed in the presence or the absence of a potent monovalent competitive inhibitor, suggested two different multivalent binding modes depending on the nature of the glycosidase involved. For glycosidases known to possess relatively deep catalytic sites, the latter would be only marginally involved in multivalent binding events, leading to poor response to multivalent ligand presentation. Most of the stabilizing interactions in the enzyme-inhibitor complexes would arise from non-catalytic sites located at the protein surface and the inhibition would be only due to the blockage of the catalytic site entrance. This mechanistic model has been demonstrated by competitive assays ${ }^{14}$ for yeast maltase which belongs to the glycosyl hydrolase family GH13. It could be applied to other glycosidases of the GH13 family or known to have buried active sites such as GH1 or GH27 glycosyl hydrolases. Jack bean $\alpha$-mannosidase (JB $\alpha$-man), which belongs to the glycosyl hydrolase GH38 family, is the glycosidase, being the most sensitive to multivalent presentation known to date. Despite the fact that the 3-D crystallographic structure of JB $\alpha$-man is currently unknown, it is believed, by analogy with other members of the GH38 family, that this enzyme possesses an open active site cleft with several sugar-binding subsites. Due to this structural feature, interactions with non-catalytic sites and specific interactions with a more accessible catalytic site would be simultaneously involved in binding events leading to strong multivalent effects via chelation mechanisms. The multivalent-binding model presented above is thus based on two scenarios involving either just interactions at non-catalytic sites or the concerted occurrence of both active site and non-catalytic site-interactions. Whereas iminosugar glycomimetics are ideally suited to bind at the catalytic site of glycosidases, it remains uncertain whether or not the interactions with the non-catalytic sites involved in multivalent enzyme inhibition are governed by similar principles. To explore this hypothesis, we have now designed neoglycoclusters as molecular probes in which the iminosugar-based specific active-site-directed inhibitory epitopes (inhitopes) were replaced by $C$-glycoside motifs, with an expected weaker affinity for the catalytic site. Here, we describe the full details of our study from $C$-glycoside cluster synthesis to the contrasted inhibition results obtained whether the glycosidase active-site is supposed to be involved or not in the multivalent binding events.

\section{Results and discussion}

\section{Neoglycocluster design}

The mechanistic probes we wanted to construct needed first to be close analogues of iminosugar click clusters such as $\mathbf{1}$ which are known to display significant inhibitory multivalent effects (Fig. 1). ${ }^{1,2}$ Secondly, these neoglycoclusters have to be based on inhitopes that should be hydrolytically stable ${ }^{18}$ and structurally as close as possible as iminosugars without displaying their selectivity towards glycosidase active-sites. To achieve this objective,
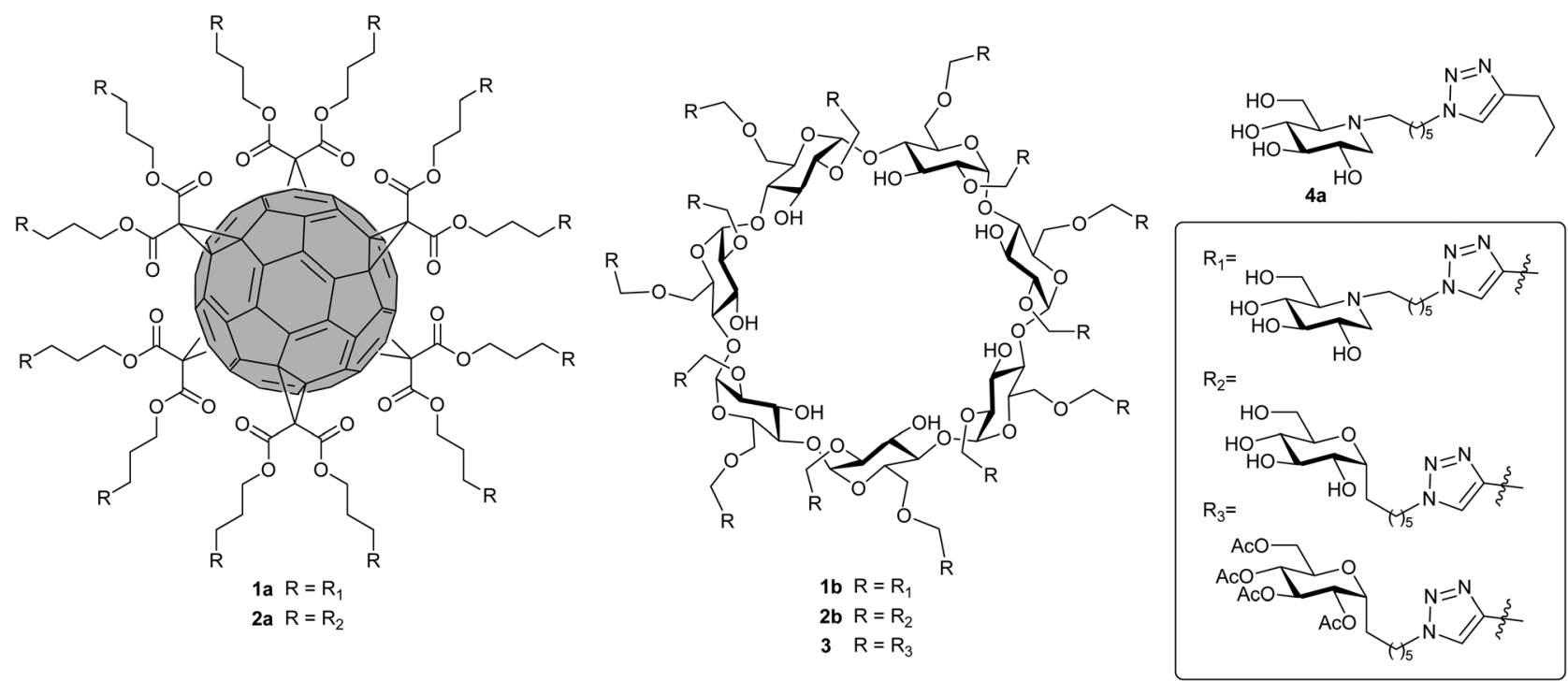

Fig. 1 Mono- and multivalent glycomimetics. 
we selected a $C$-glycosidic motif. The absence of a basic nitrogen atom was indeed expected to suppress key electrostatic interactions with nucleophilic catalytic residues and thus inhitope affinity with minimal structural modifications.

[60]Fullerene $\left(\mathrm{C}_{60}\right)$ and $\beta$-cyclodextrin $(\beta-\mathrm{CD})$ were selected since these platforms have led, in previous studies, to clusters displaying large multivalent effects with relative inhibition potency on molar basis (rp/n) up to 620 -fold. ${ }^{1,2}$

\section{Neoglycocluster synthesis}

Based on these design criteria, we targeted multivalent $C$-glycosides 2 differing by the nature of their central core (Fig. 1). As shown in Scheme 1, the synthesis began with the preparation of the azide-armed $C$-glycosides $\mathbf{9}$ and $\mathbf{1 0}$ from methyl tetra-O-benzylD-glucopyranoside (5). Following the protocol of Hosomi and Sakurai, ${ }^{19}$ compound $\mathbf{5}$ was reacted with allyltrimethylsilane in the presence of TMSOTf. This efficient process afforded $\alpha$-C-allyl glycoside $6 \mathrm{a}^{20}$ in $73 \%$ yield after purification on silica gel, the minor $\beta$-epimer $\mathbf{6 b}$ being obtained in $7 \%$ yield.

Our objective was then to perform a cross-metathesis reaction to complete the construction of the linker and functionalize the terminal position with a tosyl group. Unfortunately, our first attempts towards this goal were unsuccessful. The reaction of 4-penten-1-yl tosylate ${ }^{21}$ with $\alpha$-C-allyl glycoside 6a in the presence of the Hoveyda-Grubbs II catalyst led to an inseparable mixture of the expected product along with the two corresponding analogues bearing a $\mathrm{C}_{5}$ or a $\mathrm{C}_{7}$ alkyl spacer as judged by NMR and MS analysis. This product distribution resulted from olefin isomerization/migration in the reactants during the cross-metathesis step. ${ }^{22}$ After optimization, compound 7 was obtained in $68 \%$ yield using an additive to the cross-metathesis ruthenium catalyst (Table S1 in the ESI $\dagger$ ). Specifically, treatment of $\mathbf{6 a}$ and 4-penten-1-yl tosylate with

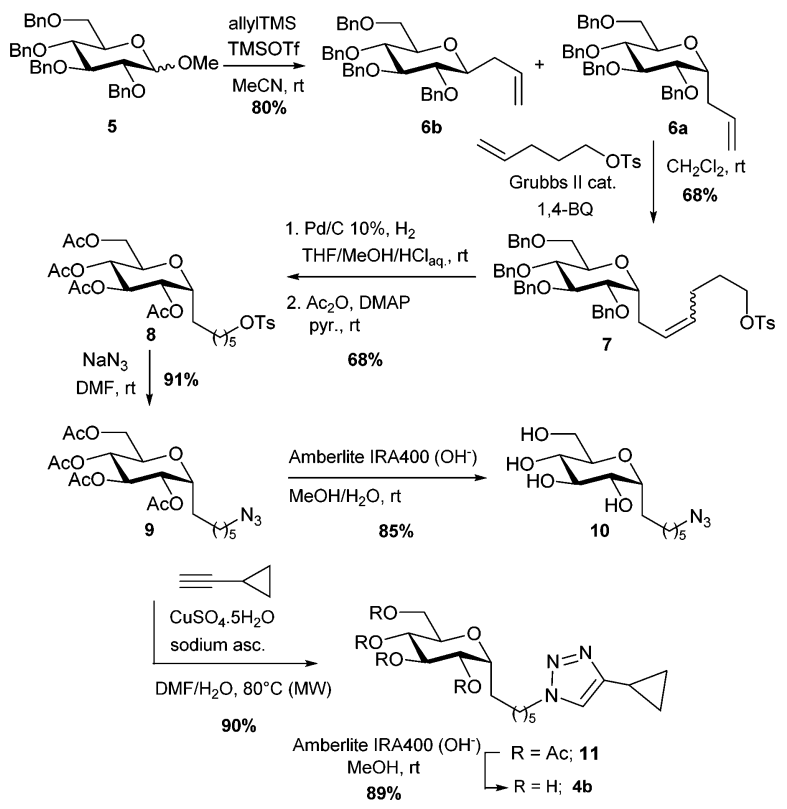

Scheme 1 Synthesis of azide-armed C-glycosides 9-10 and of the monovalent model $\mathbf{4 b}$. the Grubbs II catalyst (15 mol\%) in the presence of 1,4-benzoquinone (1,4-BQ, $20 \mathrm{~mol} \%)$ at room temperature was found to prevent the formation of the $\mathrm{C}_{5}$ and $\mathrm{C}_{7}$ byproducts. Under these conditions, 1,4-BQ is believed to oxidize ruthenium hydrides resulting from the decomposition of the metathesis catalyst and which are responsible for the olefin isomerization sidereactions. $^{22,23}$ The selective one-step removal of the benzyl protecting groups and reduction of the double bond in 7 were performed by catalytic hydrogenolysis with $\mathrm{H}_{2} / \mathrm{Pd}-\mathrm{C}$. The resulting crude tetrol product obtained was directly converted to the corresponding tetraacetate. Compound $\mathbf{8}$ was thus obtained in 68\% yield from 7 (two steps). The displacement of the tosyl group with sodium azide was achieved in $91 \%$ yield in DMF to provide the desired protected substrate $\mathbf{9}$ for azidealkyne cycloaddition coupling with the $\beta$-CD-based scaffold $12^{24}$ (Scheme 2). Compound 10, the fully deprotected analogue of 9, prepared for the $\mathrm{Cu}(\mathrm{I})$-catalyzed azide-alkyne cycloaddition (CuAAC) with fullerene hexa-adduct 13, was obtained using anion exchange Amberlite IRA-400 $\left(\mathrm{OH}^{-}\right)$resin. To assess any possible multivalent effect, $C$-glycoside 9 was reacted with ethynylcyclopropane in the presence of $\mathrm{CuSO}_{4} \cdot 5 \mathrm{H}_{2} \mathrm{O}$ and sodium ascorbate to yield, after deprotection, the corresponding adduct $\mathbf{4 b}$ used as monovalent control. It can be noted that a cyclopropyl residue was used for $\mathbf{4 b}$ and not an $n$-propyl one as in the case of $\mathbf{4 a}$. Actually, the reaction between $\mathbf{9}$ and 1-pentyne was attempted but it led to side-products ${ }^{12 b}$ arising from prior aerobic copper-catalyzed oxygenation at the propargylic methylene group. We found that this problem could be avoided by using the cyclopropylated alkyne as starting material for the preparation of the $C$-glycoside model compound. Having in hands the key azide-armed $C$-glycosides 9 and 10, we then performed the final steps of the cluster synthesis (Schemes 2 and 3).

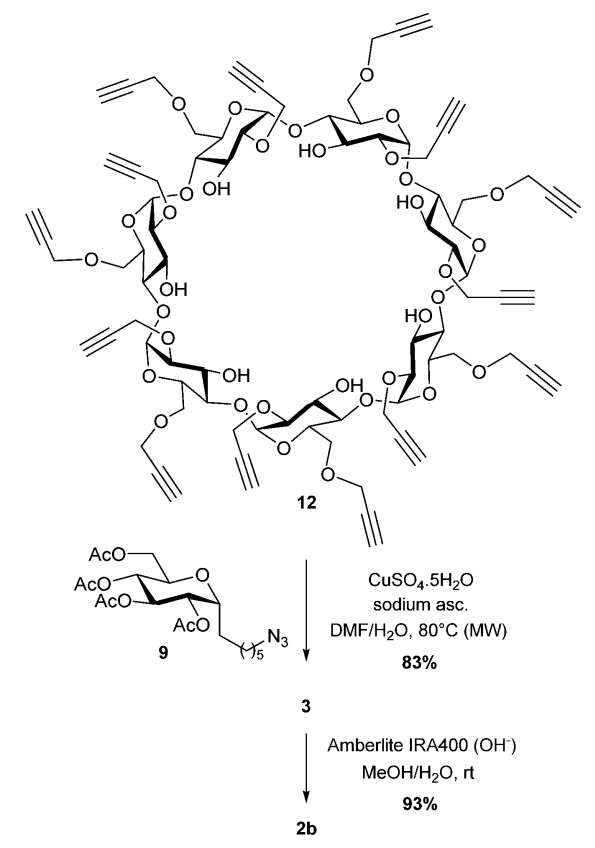

Scheme 2 Synthesis of $\mathbf{C}$-glycoside cluster $\mathbf{2 b}$. 

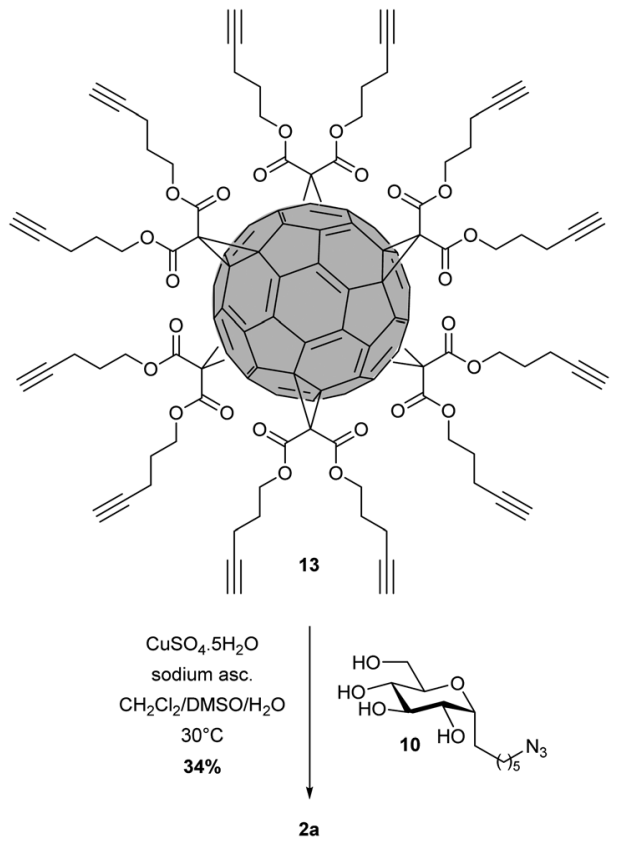

Scheme 3 Synthesis of C-glycoside cluster 2 a.

Microwave-assisted click conjugation of 9 and heptakis(2,6di-O-propargyl) $\beta$-cyclodextrin $\mathbf{1 2}^{\mathbf{2 4}}$ led to the desired tetradecavalent $C$-glycoside 3 in $83 \%$ yield (Scheme 2 ). Copper residues were removed at this stage following a simple protocol based on the filtration of the crude product on a pad of silica gel using ammonia as a complexing agent in the eluent before purification by flash chromatography. This purification process have previously demonstrated its efficiency for the synthesis of iminosugar click clusters leading to low content of residual copper ions (60 ppm) as measured by inductively coupled plasma atomic emission spectroscopy (ICP-AES). ${ }^{3}$ Subsequent $O$-deacetylation of adduct 3 using anion exchange Amberlite IRA-400 $\left(\mathrm{OH}^{-}\right)$resin afforded the expected cluster $2 \mathbf{b}$ in high yield. Compound $\mathbf{2 b}$ showed good solubility in water. For the preparation of $\mathbf{2 a}$, the fullerene scaffold $13^{25}$ had to be directly functionalized with the unprotected $C$-glycoside as the presence of the malonic esters on the $\mathrm{C}_{60}$ core is not compatible with the reaction conditions used for the deacetylation of a protected analogue. The click reaction between 10 and 13 was performed in a ternary solvent system $\left(\mathrm{CH}_{2} \mathrm{Cl}_{2} / \mathrm{DMSO} / \mathrm{H}_{2} \mathrm{O}\right)$ allowing the solubilisation of all the reagents but also of the final product. Importantly, no precipitation of partially clicked intermediates occurred during the course of the reaction thus allowing the complete functionalization of the scaffold. ${ }^{26}$

At the end of the reaction, the product was precipitated with methanol and dried. The work-up and purification process proved difficult because of solubility problems and copper contamination leading to modest yields of the desired product. Purification of 2a was first achieved by gel permeation chromatography (Sephadex G-25, $\mathrm{H}_{2} \mathrm{O}$ ). Although this purification protocol was typically sufficient to remove the remaining amount of copper catalyst for related glycosylated fullerene derivatives, it was not the case here and ICP-AES analysis revealed 19000 ppm of copper at this stage. This prompted us to further filter the compound over a QuadraSil ${ }^{\mathrm{TM}}$ Mercaptopropyl column. Compound 2a was finally isolated in 34\% yield and ICP-AES analysis revealed a low level of residual copper (994 ppm, i.e. a maximal concentration of $35 \mu \mathrm{M}$ during inhibition assays). ${ }^{27}$ The structure of 2a was confirmed by its $T$-symmetry deduced from the ${ }^{13} \mathrm{C}$ NMR spectrum recorded in DMSO- $d_{6}$ as well as by mass spectrometry.

\section{Biological results}

The inhibitory properties of $C$-glycosides clusters 2 as well as the monovalent control $\mathbf{4 b}$ were assayed towards a panel of commercial glycosidases, including JB $\alpha$-man and yeast maltase (Table 1). As their corresponding analogues in the iminosugar series, ${ }^{1,2}$ the mono- and multivalent $C$-glycosides were found to display no inhibition towards $\beta$-mannosidase and $\beta$-galactosidase. In contrast, iminosugar clusters 1 and $C$-glycoside clusters 2 drastically differed on their behavior against $\beta$-glucosidase (from almonds) and $\alpha$-galactosidase (from green coffee beans): whereas 1a and 1b displayed moderate to good inhibitory properties, compounds $\mathbf{2 a}$ and $\mathbf{2 b}$ showed no inhibition at concentrations up to $2 \mathrm{mM}$. In the case of yeast maltase the inhibition profile were very similar irrespective of the $C$-glycoside or iminosugar nature of the inhitope. The 12-valent fullerene clusters 1a and 2a were at the limit of exhibiting formal multivalent effects, with relative inhibition potencies relative to the monovalent references 4a and $\mathbf{4 b}$, on a valence-corrected basis $(\mathrm{rp} / n)$ close to one. The inhibitory efficiency was significantly decreased for the $\beta$-CD-based 14-valent clusters $\mathbf{1 b}$ and $\mathbf{2 b}$. Considering that $\beta$-glucosidase (almonds), $\alpha$-galactosidase (green coffee beans) and yeast maltase possess deep catalytic sites, a priori not accessible for multivalent conjugates, the above results can be interpreted in terms of the relative affinity of the different constructs for the non-catalytic sites involved in multivalent enzyme inhibition and their ability to block access of the substrate to the catalytic site. In the case of $\beta$-glucosidase (almonds) and $\alpha$-galactosidase, the presence of the iminosugar motif in the clusters is essential for binding, both fullerene and $\beta$-CD architectures being equally efficient. In the case of maltase, however, the iminosugar and the $C$-glycoside inhitope are equally efficient, but the enzyme was very sensitive to the topology of the conjugates, the fullerene conjugates affording much stronger inhibition as compared to the $\beta$-CD counterparts. The inhibitory performance of glycomimetic clusters towards $\mathrm{JB} \alpha$-man, an enzyme for which the active site and non-catalytic sites are simultaneously involved in multivalent enzyme inhibition, ${ }^{14}$ was found to be strongly dependent on the nature of the inhitope. As observed with yeast maltase, both monovalent models $\mathbf{4 a}$ and $\mathbf{4 b}$ produced weak inhibition. Yet, replacing the iminosugar inhitope by the $C$-glycoside motif had a drastic impact on the inhibition properties. Strong multivalent effects were indeed produced for the multivalent iminosugars 1 with $\mathrm{rp} / n$ up to 178 , whereas no modest relative affinity enhancements $(\mathrm{rp} / n \sim 0.5)$ were observed with 2 , the corresponding $C$-glycoside analogues. The higher differences in $\mathrm{JB} \alpha$-man inhibition potencies for multivalent than for 
Table 1 Glycosidase inhibitory activities $\left(K_{\mathrm{i}}, \mu \mathrm{M}\right)$ for the monovalent derivative (4) as well as multivalent glycomimetics (1-2) $)^{a, b}$

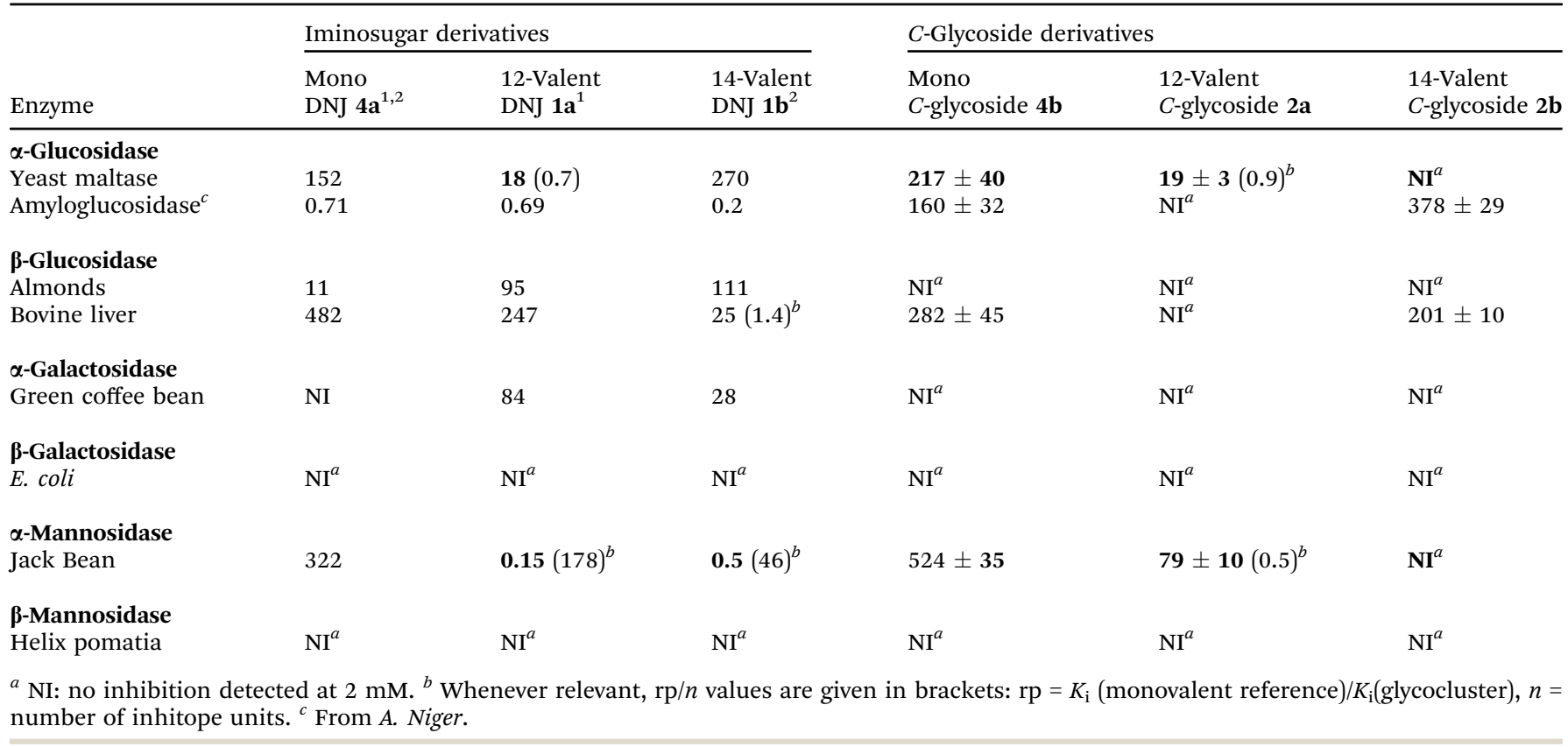

monovalent derivatives in the iminosugar and $C$-glycoside series suggest that interactions at non-catalytic sites contribute significantly to the binding affinity of the multivalent conjugates and that the iminosugar motif is better suited for such binding mode. As for maltase, a notable influence of the scaffold architecture in the inhibition performance was additionally observed, fullerene conjugates being much more efficient than $\beta$-CD derivatives. $\beta$-Glucosidase from bovine liver and amyloglucosidase from Aspergillus niger offer further examples of inhitope-dependent and scaffold-dependent multivalent enzyme inhibition. As the almond enzyme, bovine liver $\beta$-glucosidase belongs to the GH1 family and the catalytic site is not expected to participate in binding to multivalent conjugates. Whereas in monovalent form the $C$-glycoside derivative $\mathbf{4 b}$ was a two-fold better inhibitor that the iminosugar derivative $\mathbf{4 a}$, after multivalent presentation the iminosugar turned to be a much better inhitope, the $\beta$-CD conjugate 1 b becoming about 10-fold more efficient than the corresponding $C$-glycoside analogue 2b. Amyloglucosidase, a GH15 enzyme, also possesses a relatively deep glycone $(-1)$ binding site, but the aglycone $(+1)$ binding site has been shown to be relatively accessible $^{28}$ and, interestingly, to bind 1-deoxynojirimycin. ${ }^{29}$ This probably explains the strong inhibition properties of the multivalent derivatives $\mathbf{1 a}$ and $\mathbf{1} \mathbf{b}$, similar to that of the monovalent reference $4 \mathbf{a}$, in spite of the expected shift in the binding mode. A preference for the $\beta$-CD architecture was observed in this case.

\section{Conclusions}

In conclusion, we have synthesized unprecedented multivalent $C$-glycosides based on $\mathrm{C}_{60}$-fullerene or $\beta$-cyclodextrin cores. These compounds were designed as mechanistic probes to understand the molecular basis of strong inhibition of glycosidases by multivalent constructs. The inhibition results further confirmed the hypothesis that large inhibitory multivalent effects can be obtained when both glycosidase active sites and non-catalytic sites are involved in binding events, as it is the case for $\mathrm{JB} \alpha$-man. For glycosyl hydrolases with less accessible active sites, multivalent presentation of inhibitory motifs may lead to cancellation, conservation or enhancement of the inhibition capabilities. In the last two cases, binding of the multivalent conjugate occurs at noncatalytic sites of the enzyme, which makes a direct comparison with the corresponding monovalent model questionable. Instead, comparison of analogous multivalent structures led us to evaluate the efficiency of different inhitope motifs and topologies in promoting the inhibition of glycosidases. Indeed, the present body of work revealed that enzymes sensitive to multivalent enzyme inhibition can exhibit marked differences in their response to different inhitopes as well as to different architectural presentations. It is expected that the implications of these findings will be exploited in the design of potent multivalent glycosidase inhibitors.

\section{Experimental section}

Solvents were of reagent grade and further dried when necessary. Dichloromethane $\left(\mathrm{CH}_{2} \mathrm{Cl}_{2}\right)$ was distilled over $\mathrm{CaH}_{2}$ under argon. Pyridine was distilled over $\mathrm{KOH}$ under argon and stored over KOH. Dry acetonitrile and dry DMF (both over molecular sieves) were purchased from commercial vendors and used as such. 4-Penten-1-yl tosylates, ${ }^{21} \mathbf{1 2}^{\mathbf{2 4}}$ and $\mathbf{1 3}{ }^{25}$ were prepared according to previously reported procedures. All reactions were performed in standard glassware and microwave reactions were carried out using Biotage microwave reactor vials and an initiator microwave synthesizer. The reactions were monitored by thin layer chromatography (TLC) on aluminium sheets coated with silica gel $60 \mathrm{~F}_{254}$ purchased from Merck KGaA. Visualization was accomplished using UV light (at $254 \mathrm{~nm}$ ) and exposure to 
TLC stains, phosphomolybdic acid or potassium permanganate, followed by heating. Flash column chromatographies were carried out on silica gel $60(230-400$ mesh, 40-63 $\mu \mathrm{m})$ purchased from Merck KGaA. ${ }^{1} \mathrm{H}$ and ${ }^{13} \mathrm{C}$ NMR experiments were carried out at $298 \mathrm{~K}$ on either a Bruker Avance $300 \mathrm{MHz}$ or a Bruker Avance III HD $400 \mathrm{MHz}$ spectrometer. The chemical shifts are reported as $\delta$ values in parts per million (ppm) relative to residual solvent signals used as an internal reference. The exponents "A" or "B" will be used for diastereotopic protons, "A" is assigned to the proton with the lowest chemical shift and " $\mathrm{B}$ " is assigned to the proton with the highest chemical shift. Assignments of ${ }^{1} \mathrm{H}$ and ${ }^{13} \mathrm{C}$ signals were made by DEPT, ${ }^{1} \mathrm{H}-{ }^{1} \mathrm{H}$ COSY, HSQC and HMBC experiments. For convenience the assignment of ${ }^{1} \mathrm{H}$ and ${ }^{13} \mathrm{C}$ for all the molecules was based on the same numbering (see ESI $\dagger$ ). Optical rotations were measured at $589 \mathrm{~nm}$ (sodium lamp) and $20{ }^{\circ} \mathrm{C}$ on either a Perkin-Elmer 341 polarimeter or an Anton Paar MCP 200 polarimeter with a path length of $1 \mathrm{dm}$. The concentration $(c)$ is indicated in gram per deciliter. Infrared (IR) spectra were recorded neat on a Perkin-Elmer Spectrum Two FT-IR spectrometer. High-resolution (HRMS) electrospray ionization-time-of-flight (ESI-TOF) mass spectra were recorded on a Bruker micrOTOF ${ }^{\circledR}$ mass spectrometer. Residual copper ions traces were measured on an Inductively Coupled Plasma Optical Emission Spectrometer (Varian 720-ES) at $324.754 \mathrm{~nm}$.

\section{$\alpha$-1-C-Allyl-2,3,4,6-tetra- $O$-benzyl-1-deoxy-D-glucopyranose 6 a}

At rt, allyltrimethylsilane $(1.75 \mathrm{~mL}, 11.01 \mathrm{mmol}, 3$ eq.) was added to a solution of $5(2.01 \mathrm{~g}, 3.62 \mathrm{mmol})$ in dry MeCN $(20 \mathrm{~mL})$ and the solution was stirred for $30 \mathrm{~min}$. The solution was then cooled to $0{ }^{\circ} \mathrm{C}$ and TMSOTf $(0.66 \mathrm{~mL}, 3.65 \mathrm{mmol}$, 1 eq.) was added dropwise. The reaction mixture was allowed to warm to rt and stirred for $19 \mathrm{~h}$. $\mathrm{Et}_{2} \mathrm{O}$ was added and the organic layer was successively washed with sat. aqueous $\mathrm{NaHCO}_{3}$, water and brine, dried over $\mathrm{Na}_{2} \mathrm{SO}_{4}$, filtered and concentrated under reduced pressure. The crude residue was purified by flash column chromatography $\left(\mathrm{Et}_{2} \mathrm{O} /\right.$ petroleum ether, $\left.20: 80\right)$ to afford $\mathbf{6 a}(1.49 \mathrm{~g}, 73 \%)$ and $\mathbf{6 b}(150 \mathrm{mg}, 7 \%)$ as white solids. The analytical data of $6 \mathbf{a}$ were in complete agreement with those reported in the literature. ${ }^{20}$

$R_{\mathrm{f}} 0.42\left(\mathrm{Et}_{2} \mathrm{O} /\right.$ petroleum ether, $\left.20: 80\right) ;{ }^{1} \mathrm{H}-\mathrm{NMR}(400 \mathrm{MHz}$, $\left.\mathrm{CDCl}_{3}\right) \delta 2.46-2.58\left(\mathrm{~m}, 2 \mathrm{H} ; \mathrm{CH}_{2}-7\right), 3.61-3.86(\mathrm{~m}, 6 \mathrm{H} ; \mathrm{H}-2, \mathrm{H}-3$, $\mathrm{H}-4, \mathrm{H}-5$ and $\left.\mathrm{CH}_{2}-6\right), 4.16$ (ddd, $J=10.2,5.4,4.8 \mathrm{~Hz}, 1 \mathrm{H} ; \mathrm{H}-1$ ), $4.50\left(\mathrm{~d}, J=12.2 \mathrm{~Hz}, 1 \mathrm{H} ; \mathrm{CH}_{2} \mathrm{Ph}\right), 4.50(\mathrm{~d}, J=10.6 \mathrm{~Hz}, 1 \mathrm{H}$; $\mathrm{CH}_{2} \mathrm{Ph}$ ), 4.65 (d, $\left.J=12.2 \mathrm{~Hz}, 1 \mathrm{H} ; \mathrm{CH}_{2} \mathrm{Ph}\right), 4.66$ (d, $J=11.6 \mathrm{~Hz}$, $\left.1 \mathrm{H} ; \mathrm{CH}_{2} \mathrm{Ph}\right), 4.72$ (d, $\left.J=11.6 \mathrm{~Hz}, 1 \mathrm{H} ; \mathrm{CH}_{2} \mathrm{Ph}\right), 4.83(\mathrm{~d}, J=$ $11.0 \mathrm{~Hz}, 1 \mathrm{H} ; \mathrm{CH}_{2} \mathrm{Ph}$ ), 4.84 (d, $\left.J=10.6 \mathrm{~Hz}, 1 \mathrm{H} ; \mathrm{CH}_{2} \mathrm{Ph}\right), 4.96$ (d, $J=11.0 \mathrm{~Hz}, 1 \mathrm{H} ; \mathrm{CH}_{2} \mathrm{Ph}$ ), 5.10 (dd, $J=10.0,1.5 \mathrm{~Hz}, 1 \mathrm{H} ; \mathrm{H}^{\mathrm{B}}-9$ ), 5.14 (dd, $J=17.1,1.5 \mathrm{~Hz}, 1 \mathrm{H} ; \mathrm{H}^{\mathrm{A}}-9$ ), 5.85 (ddt, $J=17.1,10.0$ and $7.0 \mathrm{~Hz}, 1 \mathrm{H} ; \mathrm{H}-8), 7.12-7.18\left(\mathrm{~m}, 2 \mathrm{H} ; \mathrm{H}_{\mathrm{Ar}}\right), 7.26-7.39(\mathrm{~m}$, $18 \mathrm{H} ; \mathrm{H}_{\mathrm{Ar}}$ ); ${ }^{13} \mathrm{C}-\mathrm{NMR}\left(100 \mathrm{MHz}, \mathrm{CDCl}_{3}\right) \delta 30.0$ (C-7), 69.1 (C-6), 71.3 (C-5), $73.2\left(\mathrm{CH}_{2} \mathrm{Ph}\right), 73.6\left(\mathrm{CH}_{2} \mathrm{Ph}\right), 73.9(\mathrm{C}-1), 75.2\left(\mathrm{CH}_{2} \mathrm{Ph}\right)$, $75.6\left(\mathrm{CH}_{2} \mathrm{Ph}\right), 78.3$ (C-4), 80.2 (C-2), 82.6 (C-3), 117.0 (C-9), $127.7,127.8$, 127.9, 127.96, 128.01, 128.07, 128.12, 128.47, 128.53, $128.6\left(20 \times \mathrm{CH}_{\mathrm{Ar}}\right), 134.9(\mathrm{C}-8), 138.2,138.3,138.4$, $138.9\left(4 \times \mathrm{C}_{\mathrm{Ar}}\right)$.

\section{2,3,4,6-Tetra-O-benzyl-1-deoxy-1-C-[6-(tosyloxy)hex-2-en-1-yl]- $\alpha$ -} D-glucopyranose 7

An oven-dried Schlenk tube was charged with 6a (52 mg, $0.0921 \mathrm{mmol})$, 4-penten-1-yl tosylate $(120 \mathrm{mg}, 0.4993 \mathrm{mmol}$, 5.4 eq.), 1,4-benzoquinone ( $2 \mathrm{mg}, 0.0185 \mathrm{mmol}, 0.2 \mathrm{eq}$.) and the Grubbs II catalyst ( $7.7 \mathrm{mg}, 0.0091 \mathrm{mmol}, 0.1 \mathrm{eq}$.). The Schlenk tube was evacuated under vacuum and backfilled with argon (three cycles). Dry and degassed $\mathrm{CH}_{2} \mathrm{Cl}_{2}(1.2 \mathrm{~mL})$ was added and the reaction mixture was stirred at rt under argon for $6 \mathrm{~h}$. Additional Grubbs 2nd generation catalyst $(3.9 \mathrm{mg}, 0.0046 \mathrm{mmol}$, 0.05 eq.) was added to the reaction mixture, followed by additional stirring for $64 \mathrm{~h}$. The reaction mixture was concentrated under reduced pressure. The crude residue was purified by flash column chromatography (EtOAc/petroleum ether, 15:85 to 20:80; solid deposition) to afford 7 (49 $\mathrm{mg}, 68 \%)$ as a mixture of $E / Z$ isomers (colorless oil).

$R_{\mathrm{f}} 0.34$ (EtOAc/petroleum ether, 20:80); IR (neat) 1175, $1360 \mathrm{~cm}^{-1}$; ${ }^{1} \mathrm{H}-\mathrm{NMR}\left(400 \mathrm{MHz}, \mathrm{CDCl}_{3}\right) \delta 1.62-1.72(\mathrm{~m}, 2 \mathrm{H}$; $\mathrm{CH}_{2}-11$ ), 1.96-2.08 (m, 2H; $\left.\mathrm{CH}_{2}-10\right)$, 2.31-2.46 (m, 5H; $\mathrm{CH}_{2}-7$ and $\left.\mathrm{CH}_{3}\right), 3.53-3.81\left(\mathrm{~m}, 6 \mathrm{H} ; \mathrm{H}-2, \mathrm{H}-3, \mathrm{H}-4, \mathrm{H}-5\right.$ and $\left.\mathrm{CH}_{2}-6\right)$, 3.96-4.06 (m, 3H; H-1 and $\left.\mathrm{CH}_{2}-12\right)$, 4.43-4.50 (m, 2H; $\mathrm{CH}_{2} \mathrm{Ph}$ ), 4.57-4.64 (m, 2H; $\left.\mathrm{CH}_{2} \mathrm{Ph}\right), 4.65-4.71$ (m, $\left.1 \mathrm{H} ; \mathrm{CH}_{2} \mathrm{Ph}\right), 4.77-4.83$ (m, 2H; $\left.\mathrm{CH}_{2} \mathrm{Ph}\right), 4.90-4.96\left(\mathrm{~m}, 1 \mathrm{H} ; \mathrm{CH}_{2} \mathrm{Ph}\right), 5.30-5.45(\mathrm{~m}, 2 \mathrm{H}$; $\mathrm{H}-8$ and $\mathrm{H}-9), 7.10-7.15\left(\mathrm{~m}, 2 \mathrm{H} ; \mathrm{H}_{\mathrm{Ar}}\right), 7.22-7.36\left(\mathrm{~m}, 20 \mathrm{H} ; \mathrm{H}_{\mathrm{Ar}}\right)$, 7.76-7.80 (m, 2H; $\left.\mathrm{H}_{\mathrm{Ar}}\right) ;{ }^{13} \mathrm{C}-\mathrm{NMR}\left(100 \mathrm{MHz}, \mathrm{CDCl}_{3}\right) \delta 21.8$ $\left(\mathrm{CH}_{3}\right)$, 28.5, 28.6, 28.7 (C-7, C-10, C-11), 69.2 (C-6), 70.1 (C-12), 71.2 (C-5), $73.2\left(\mathrm{CH}_{2} \mathrm{Ph}\right), 73.6\left(\mathrm{CH}_{2} \mathrm{Ph}\right), 74.0(\mathrm{C}-1), 75.2\left(\mathrm{CH}_{2} \mathrm{Ph}\right)$, $75.6\left(\mathrm{CH}_{2} \mathrm{Ph}\right), 78.3(\mathrm{C}-4), 80.3(\mathrm{C}-2), 82.5$ (C-3), 127.6, 127.7, 127.8, 127.88, 127.93, 128.01, 128.03, 128.05, 128.12, 128.47, 128.54, $128.6\left(\mathrm{C}-8, \mathrm{C}-9,24 \times \mathrm{CH}_{\mathrm{Ar}}\right), 134.9(\mathrm{C}-8), 133.4,138.2$, 138.3, 138.4, 138.9, $144.8\left(6 \times \mathrm{C}_{\mathrm{Ar}}\right)$; HRMS (ESI) $m / z 799.3279$ $\left([\mathrm{M}+\mathrm{Na}]^{+}\right.$, calcd for $\mathrm{C}_{47} \mathrm{H}_{52} \mathrm{O}_{8} \mathrm{SNa}$ : 799.3275).

\section{2,3,4,6-Tetra- $O$-acetyl-1-deoxy-1- $C$-[6-(tosyloxy)hexyl]- $\alpha$-D-gluco- pyranose 8}

To a solution of $7(144 \mathrm{mg}, 0.1853 \mathrm{mmol})$ in THF $(4 \mathrm{~mL})$ and $\mathrm{MeOH}(2 \mathrm{~mL})$ were added $1 \mathrm{M}$ aqueous $\mathrm{HCl}(0.25 \mathrm{~mL})$ and $\mathrm{Pd} / \mathrm{C}$ (20 mg, $0.0188 \mathrm{mmol}, 10 \% \mathrm{Pd}$ on C, 0.1 eq.). The flask was evacuated under vacuum and backfilled with argon (four cycles), and then evacuated under vacuum and backfilled with $\mathrm{H}_{2}$ (four cycles). The reaction mixture was stirred under an atmosphere of $\mathrm{H}_{2}$ (balloon) at rt for $4 \mathrm{~h}$. The reaction mixture was then filtered through a pad of Celite, previously washed first with $1 \mathrm{M}$ aqueous $\mathrm{HCl}$ (at least $250 \mathrm{~mL}$ ) and then with water. The catalyst was washed with $\mathrm{MeOH}$, and the filtrate was concentrated under reduced pressure. The crude residue was dissolved in a mixture of dry pyridine $(4 \mathrm{~mL})$ and $\mathrm{Ac}_{2} \mathrm{O}(4 \mathrm{~mL})$, and then DMAP ( $4.5 \mathrm{mg}, 0.0368 \mathrm{mmol}, 0.2 \mathrm{eq}$.) was added to the solution. The reaction mixture was stirred at $\mathrm{rt}$ for $5 \mathrm{~h}$. Solvents were evaporated under reduced pressure and the crude residue was purified by flash column chromatography (EtOAc/petroleum ether, $30: 70)$ to afford $8(74 \mathrm{mg}, 68 \%)$ as a colorless oil.

$R_{\mathrm{f}} 0.43$ (EtOAc/petroleum ether, $\left.40: 60\right) ;[\alpha]_{\mathrm{D}}^{20}+40(c$ 1.0, $\mathrm{CHCl}_{3}$ ); IR (neat) 1175, 1365, $1744 \mathrm{~cm}^{-1}$; ${ }^{1} \mathrm{H}-\mathrm{NMR}(400 \mathrm{MHz}$, $\left.\mathrm{CDCl}_{3}\right) \delta$ 1.22-1.48 (m, 7H; $\mathrm{H}^{\mathrm{A}}-7, \mathrm{CH}_{2}-8, \mathrm{CH}_{2}-9$ and $\left.\mathrm{CH}_{2}-10\right)$, 
1.59-1.68 (m, 2H; $\left.\mathrm{CH}_{2}-11\right), 1.69-1.80\left(\mathrm{~m}, 1 \mathrm{H} ; \mathrm{H}^{\mathrm{B}}-7\right), 2.02$ $\left(\mathrm{s}, 3 \mathrm{H} ; \mathrm{C}(\mathrm{O}) \mathrm{CH}_{3}\right), 2.03\left(\mathrm{~s}, 3 \mathrm{H} ; \mathrm{C}(\mathrm{O}) \mathrm{CH}_{3}\right), 2.04\left(\mathrm{~s}, 3 \mathrm{H} ; \mathrm{C}(\mathrm{O}) \mathrm{CH}_{3}\right)$, 2.07 (s, 3H; C(O)CH $\left.\mathrm{CH}_{3}\right), 2.45$ (s, 3H; $\mathrm{CH}_{3}$ ), 3.79 (ddd, $J=9.4,5.3$ and $2.3 \mathrm{~Hz}, 1 \mathrm{H} ; \mathrm{H}-5), 4.01\left(\mathrm{t}, J=6.4 \mathrm{~Hz}, 2 \mathrm{H} ; \mathrm{CH}_{2}-12\right), 4.07$ (dd, $J=12.1,2.3 \mathrm{~Hz}, 1 \mathrm{H} ; \mathrm{H}^{\mathrm{A}}-6$ ), 4.09-4.16 (m, 1H; H-1), 4.22 (dd, $\left.J=12.1,5.3 \mathrm{~Hz}, 1 \mathrm{H} ; \mathrm{H}^{\mathrm{B}}-6\right), 4.96$ (dd, $\left.J=9.4,8.8 \mathrm{~Hz}, 1 \mathrm{H} ; \mathrm{H}-4\right)$, 5.05 (dd, $J=9.5,5.7 \mathrm{~Hz}, 1 \mathrm{H} ; \mathrm{H}-2), 5.30(\mathrm{dd}, J=9.5,8.8 \mathrm{~Hz}, 1 \mathrm{H}$; $\mathrm{H}-3), 7.35$ (d, $J=8.1 \mathrm{~Hz}, 2 \mathrm{H} ; \mathrm{H}_{\mathrm{Ar}}$ ), $7.78\left(\mathrm{~d}, J=8.1 \mathrm{~Hz}, 2 \mathrm{H} ; \mathrm{H}_{\mathrm{Ar}}\right.$ ); ${ }^{13} \mathrm{C}-\mathrm{NMR}\left(100 \mathrm{MHz}, \mathrm{CDCl}_{3}\right) \delta 20.7\left(\mathrm{C}(\mathrm{O}) \mathrm{CH}_{3}\right), 20.75(2 \times$ $\left.\mathrm{C}(\mathrm{O}) \mathrm{CH}_{3}\right), 20.77\left(\mathrm{C}(\mathrm{O}) \mathrm{CH}_{3}\right), 21.7\left(\mathrm{CH}_{3}\right), 24.8,25.2$, 25.4, 28.6, 28.8 (C-7, C-8, C-9, C-10, C-11), 62.5 (C-6), 68.6 (C-5), 69.0 (C-4), 70.48, 70.52 (C-2, C-3, C-12), 72.5 (C-1), $127.9\left(2 \times \mathrm{CH}_{\mathrm{Ar}}\right), 129.9$ $\left(2 \times \mathrm{CH}_{\mathrm{Ar}}\right), 133.2\left(\mathrm{C}_{\mathrm{Ar}}\right), 144.8\left(\mathrm{C}_{\mathrm{Ar}}\right), 169.6,169.7,170.2,170.7$ $\left(4 \times C(\mathrm{O}) \mathrm{CH}_{3}\right)$; HRMS (ESI) $\mathrm{m} / z 609.1897\left([\mathrm{M}+\mathrm{Na}]^{+}\right.$, calcd for $\mathrm{C}_{27} \mathrm{H}_{38} \mathrm{O}_{12} \mathrm{SNa}$ : 609.1976).

\section{2,3,4,6-Tetra- $O$-acetyl-1-deoxy-1- $C$-(6-azidohexyl)- $\alpha$-D- glucopyranose 9}

$\mathrm{NaN}_{3}$ (41 mg, $0.6307 \mathrm{mmol}, 4.6$ eq.) was added to a solution of 8 $(80 \mathrm{mg}, 0.1364 \mathrm{mmol})$ in dry DMF $(2 \mathrm{~mL})$, and the reaction mixture was stirred at $\mathrm{rt}$ under argon for $17 \mathrm{~h}$. The solvent was evaporated under reduced pressure and the residue was diluted with EtOAc and washed with water $(2 \times)$ and brine. The organic layer was dried over $\mathrm{Na}_{2} \mathrm{SO}_{4}$, filtered and concentrated under reduced pressure. The crude residue was purified by flash column chromatography (EtOAc/petroleum ether, 30:70) to afford 9 (57 mg, 91\%) as a colorless solid.

$R_{\mathrm{f}} 0.30$ (EtOAc/petroleum ether, 30:70); $[\alpha]_{\mathrm{D}}^{20}+63$ (c 2.0, $\mathrm{CHCl}_{3}$ ); IR (neat) 1743, $2096 \mathrm{~cm}^{-1} ;{ }^{1} \mathrm{H}-\mathrm{NMR}$ (400 MHz, $\mathrm{CDCl}_{3}$ ) $\delta$ 1.22-1.50 (m, 7H; $\mathrm{H}^{\mathrm{A}}-7, \mathrm{CH}_{2}-8, \mathrm{CH}_{2}-9$ and $\left.\mathrm{CH}_{2}-10\right), 1.53-1.63$ (m, 2H; $\left.\mathrm{CH}_{2}-11\right), 1.70-1.81\left(\mathrm{~m}, 1 \mathrm{H} ; \mathrm{H}^{\mathrm{B}}-7\right), 2.00$ (s, 3H; C(O)CH $\mathrm{CH}_{3}$ ), 2.01 (s, 3H; C(O)CH $\left.\mathrm{CH}_{3}\right), 2.02\left(\mathrm{~s}, 3 \mathrm{H} ; \mathrm{C}(\mathrm{O}) \mathrm{CH}_{3}\right), 2.06\left(\mathrm{~s}, 3 \mathrm{H} ; \mathrm{C}(\mathrm{O}) \mathrm{CH}_{3}\right)$, $3.25\left(\mathrm{t}, J=6.8 \mathrm{~Hz}, 2 \mathrm{H} ; \mathrm{CH}_{2}-12\right.$ ), 3.78 (ddd, $J=9.4,5.3$ and $2.4 \mathrm{~Hz}, 1 \mathrm{H}$; $\mathrm{H}-5$ ), 4.05 (dd, $\left.J=12.1,2.4 \mathrm{~Hz}, 1 \mathrm{H} ; \mathrm{H}^{\mathrm{A}}-6\right), 4.10-4.17$ (m, $1 \mathrm{H} ; \mathrm{H}-1$ ), 4.21 (dd, $\left.J=12.1,5.3 \mathrm{~Hz}, 1 \mathrm{H} ; \mathrm{H}^{\mathrm{B}}-6\right), 4.95$ (dd, $J=9.4,8.9 \mathrm{~Hz}, 1 \mathrm{H}$; $\mathrm{H}-4), 5.04$ (dd, $J=9.5,5.8 \mathrm{~Hz}, 1 \mathrm{H} ; \mathrm{H}-2), 5.29$ (dd, $J=9.5,8.9 \mathrm{~Hz}, 1 \mathrm{H}$; $\mathrm{H}-3) ;{ }^{13} \mathrm{C}-\mathrm{NMR}\left(100 \mathrm{MHz}, \mathrm{CDCl}_{3}\right) \delta 20.7,20.8\left(4 \times \mathrm{C}(\mathrm{O}) \mathrm{CH}_{3}\right), 24.9$, 25.2, 26.8, 28.8, 28.9 (C-7, C-8, C-9, C-10, C-11), 51.4 (C-12), 62.5 (C-6), 68.7 (C-5), 69.0 (C-4), 70.5 (C-3), 70.6 (C-2), 72.6 (C-1), 169.6, 169.7, 170.2, $170.7\left(4 \times C(\mathrm{O}) \mathrm{CH}_{3}\right)$; HRMS (ESI) $\mathrm{m} / \mathrm{z} 480.1976$ $\left([\mathrm{M}+\mathrm{Na}]^{+}\right.$, calcd for $\mathrm{C}_{20} \mathrm{H}_{31} \mathrm{~N}_{3} \mathrm{O}_{9} \mathrm{Na}$ : 480.1953).

\section{$\alpha-1-C$-(6-Azidohexyl)-1-deoxy-D-glucopyranose 10}

To a solution of 9 (130 mg, $0.2842 \mathrm{mmol})$ in a mixture of $\mathrm{MeOH}$ (7 mL) and $\mathrm{H}_{2} \mathrm{O}(7 \mathrm{~mL})$ was added Amberlite IRA400 $\left(\mathrm{OH}^{-}\right)$ resin $(3.5 \mathrm{~g})$. The mixture was stirred using a rotavapor at $\mathrm{rt}$ for $18 \mathrm{~h}$. The resin was then filtered, rinsed with $\mathrm{MeOH}$ and the filtrate was concentrated under reduced pressure. The crude residue was purified by flash column chromatography $\left(\mathrm{CH}_{2} \mathrm{Cl}_{2} /\right.$ $\mathrm{MeOH}, 90: 10)$ to afford $\mathbf{1 0}(70 \mathrm{mg}, 85 \%)$ as a colorless oil.

$R_{\mathrm{f}} 0.28\left(\mathrm{CH}_{2} \mathrm{Cl}_{2} / \mathrm{MeOH}, 90: 10\right) ;[\alpha]_{\mathrm{D}}^{20}+69$ (c 2.0, MeOH); IR (neat) 2096, $3353 \mathrm{~cm}^{-1} ;{ }^{1} \mathrm{H}-\mathrm{NMR}\left(400 \mathrm{MHz}, \mathrm{CD}_{3} \mathrm{OD}\right) \delta 1.26-1.48$ (m, 5H; $\mathrm{H}^{\mathrm{A}}-7, \mathrm{CH}_{2}-9$ and $\left.\mathrm{CH}_{2}-10\right), 1.49-1.75\left(\mathrm{~m}, 5 \mathrm{H} ; \mathrm{H}^{\mathrm{B}}-7, \mathrm{CH}_{2}-8\right.$ and $\left.\mathrm{CH}_{2}-11\right), 3.21-3.34\left(\mathrm{~m}, 3 \mathrm{H} ; \mathrm{H}-4\right.$ and $\left.\mathrm{CH}_{2}-12\right)$, 3.35-3.43 (m, 1H; H-5), 3.50-3.68 (m, 3H; H-2, H-3 and $\left.\mathrm{H}^{\mathrm{A}}-6\right), 3.75-3.82$ (m, 1H; $\left.\mathrm{H}^{\mathrm{B}}-6\right)$, 3.84-3.92 (m, 1H; H-1); ${ }^{13} \mathrm{C}-\mathrm{NMR}\left(100 \mathrm{MHz}, \mathrm{CD}_{3} \mathrm{OD}\right)$ $\delta$ 25.2, 26.5, 27.8, 29.8, 30.0 (C-7, C-8, C-9, C-10, C-11), 52.4 (C-12), 63.1 (C-6), 72.4 (C-4), 73.1 (C-2), 74.3 (C-5), 75.3 (C-3), 77.2 (C-1); HRMS (ESI) $\mathrm{m} / \mathrm{z} 312.1556\left([\mathrm{M}+\mathrm{Na}]^{+}\right.$, calcd for $\mathrm{C}_{12} \mathrm{H}_{23} \mathrm{~N}_{3} \mathrm{O}_{5} \mathrm{Na}$ : 312.1530).

\section{2,3,4,6-Tetra-O-acetyl-1- $C$-[6-(4-cyclopropyl-1H-1,2,3-triazol-1- yl)hexyl]-1-deoxy- $\alpha$-D-glucopyranose 11}

To a solution of 9 (29 mg, $0.0634 \mathrm{mmol})$ and ethynylcyclopropane (0.02 mL, $0.2363 \mathrm{mmol}, 3.7$ eq.) in DMF (1.7 mL) in a microwave vial was added a yellow suspension of $\mathrm{CuSO}_{4} \cdot 5 \mathrm{H}_{2} \mathrm{O}(2 \mathrm{mg}$, $0.0080 \mathrm{mmol}, 0.13 \mathrm{eq}$.) and sodium ascorbate ( $3 \mathrm{mg}, 0.0151 \mathrm{mmol}$, 0.24 eq. $)$ in water $(0.45 \mathrm{~mL})$. The resulting suspension was stirred and heated under microwave irradiation at $80{ }^{\circ} \mathrm{C}$ for $30 \mathrm{~min}$. Additional ethynylcyclopropane $(0.02 \mathrm{~mL}, 0.2363 \mathrm{mmol}, 3.7 \mathrm{eq}$.) was added and the reaction mixture was stirred and heated under microwave irradiation at $80{ }^{\circ} \mathrm{C}$ for another $30 \mathrm{~min}$. The reaction mixture was diluted with water and extracted with EtOAc $(3 \times)$. The combined organic extracts were washed with water $(3 \times)$, dried over $\mathrm{Na}_{2} \mathrm{SO}_{4}$, filtered and concentrated under reduced pressure. The residue was diluted with a mixture of $\mathrm{MeCN} / \mathrm{H}_{2} \mathrm{O} / \mathrm{NH}_{4} \mathrm{OH}(10: 1: 1)$ and filtered through a pad of silica gel, using the same mixture as the eluent. Copper salts precipitated as a blue powder and remained at the top of the silica gel pad. The filtrate was concentrated under reduced pressure and the crude residue was purified by flash column chromatography (EtOAc/petroleum ether, $70: 30)$ to afford 11 (30 mg, 90\%) as a colorless solid.

$R_{\mathrm{f}} 0.36$ (EtOAc/petroleum ether, 70:30); $[\alpha]_{\mathrm{D}}^{20}+54(c$ 1.0, $\mathrm{CHCl}_{3}$ ); IR (neat) $1746 \mathrm{~cm}^{-1}$; ${ }^{1} \mathrm{H}-\mathrm{NMR}\left(400 \mathrm{MHz}, \mathrm{CDCl}_{3}\right)$ $\delta$ 0.78-0.96 (m, 4H; $\mathrm{CH}_{2}-16$ and $\left.\mathrm{CH}_{2}-17\right), 1.18-1.49(\mathrm{~m}, 7 \mathrm{H}$; $\mathrm{H}^{\mathrm{A}}-7, \mathrm{CH}_{2}-8, \mathrm{CH}_{2}-9$ and $\left.\mathrm{CH}_{2}-10\right), 1.67-1.80\left(\mathrm{~m}, 1 \mathrm{H} ; \mathrm{H}^{\mathrm{B}}-7\right), 1.81-$ $1.96\left(\mathrm{~m}, 3 \mathrm{H} ; \mathrm{CH}_{2}-11\right.$ and $\left.\mathrm{H}-15\right), 2.01\left(\mathrm{~s}, 6 \mathrm{H} ; 2 \times \mathrm{C}(\mathrm{O}) \mathrm{CH}_{3}\right), 2.03$ $\left(\mathrm{s}, 3 \mathrm{H} ; \mathrm{C}(\mathrm{O}) \mathrm{CH}_{3}\right), 2.05$ (s, 3H; C(O)CH $\mathrm{CH}_{3}, 3.73-3.81$ (m, $\left.1 \mathrm{H} ; \mathrm{H}-5\right)$, 4.02-4.09 (m, 1H; $\left.\mathrm{H}^{\mathrm{A}}-6\right), 4.09-4.16(\mathrm{~m}, 1 \mathrm{H} ; \mathrm{H}-1), 4.17-4.31$ $\left(\mathrm{m}, 3 \mathrm{H} ; \mathrm{H}^{\mathrm{B}}-6\right.$ and $\left.\mathrm{CH}_{2}-12\right)$, 4.91-4.99 (m, 1H; H-4), 5.00-5.08 (m, 1H; H-2), 5.24-5.32 (dd, $J=9.2 \mathrm{~Hz}, 1 \mathrm{H} ; \mathrm{H}-3), 7.20(\mathrm{~s}, 1 \mathrm{H}$; $\mathrm{H}-13) ;{ }^{13} \mathrm{C}-\mathrm{NMR}\left(100 \mathrm{MHz}, \mathrm{CDCl}_{3}\right) \delta 6.8$ (C-15), 7.8 (C-16, C-17), 20.76, 20.82, $20.9\left(4 \times \mathrm{C}(\mathrm{O}) \mathrm{CH}_{3}\right), 24.9,25.3,26.6,28.8$ (C-7, C-8, C-9, C-10), 30.3 (C-11), 50.1 (C-12), 62.5 (C-6), 68.7 (C-5), 69.0 (C-4), 70.5, 70.6 (C-2, C-3), 72.6 (C-1), 119.5 (C-13), 150.3 (C-14), 169.6, 169.8, 170.3, $170.7\left(4 \times C(\mathrm{O}) \mathrm{CH}_{3}\right) ; \mathrm{HRMS}(\mathrm{ESI}) \mathrm{m} / \mathrm{z}$ $524.2628\left([\mathrm{M}+\mathrm{H}]^{+}\right.$, calcd for $\mathrm{C}_{25} \mathrm{H}_{38} \mathrm{~N}_{3} \mathrm{O}_{9}$ : 524.2603).

\section{$\alpha-1-C$-[6-(4-Cyclopropyl-1H-1,2,3-triazol-1-yl)hexyl]-1-deoxy-D-} glucopyranose $4 \mathrm{~b}$

To a solution of 11 (28 mg, $0.0535 \mathrm{mmol}$ ) in $\mathrm{MeOH}(3 \mathrm{~mL})$ was added Amberlite IRA400 $\left(\mathrm{OH}^{-}\right)$resin $(1.0 \mathrm{~g})$. The mixture was stirred using a rotavapor at $\mathrm{rt}$ for $16 \mathrm{~h}$. The resin was then filtered, rinsed with $\mathrm{MeOH}$ and the filtrate was concentrated under reduced pressure. The crude residue was purified by flash column chromatography $\left(\mathrm{CH}_{2} \mathrm{Cl}_{2} / \mathrm{MeOH}, 90: 10\right.$ to $\left.85: 15\right)$ to afford $4 \mathbf{b}(17 \mathrm{mg}, 89 \%)$ as a colorless oil.

$R_{\mathrm{f}} 0.20\left(\mathrm{CH}_{2} \mathrm{Cl}_{2} / \mathrm{MeOH}, 90: 10\right) ;[\alpha]_{\mathrm{D}}^{20}+53(c$ 1.0, $\mathrm{MeOH}) ; \mathrm{IR}$ (neat) $3340 \mathrm{~cm}^{-1} ;{ }^{1} \mathrm{H}-\mathrm{NMR}\left(400 \mathrm{MHz}, \mathrm{CD}_{3} \mathrm{OD}\right) \delta 0.72-0.79(\mathrm{~m}$, $2 \mathrm{H} ; \mathrm{CH}_{2}-16$ or $\mathrm{CH}_{2}-17$ ), 0.91-1.00 (m, 2H; $\mathrm{CH}_{2}-16$ or $\mathrm{CH}_{2}-17$ ), 1.24-1.45 (m, 5H; $\mathrm{H}^{\mathrm{A}}-8, \mathrm{CH}_{2}-9$ and $\left.\mathrm{CH}_{2}-10\right)$, 1.47-1.71 (m, 3H; $\mathrm{CH}_{2}-7$ and $\left.\mathrm{H}^{\mathrm{B}}-8\right), 1.83-1.99\left(\mathrm{~m}, 3 \mathrm{H} ; \mathrm{CH}_{2}-11\right.$ and $\left.\mathrm{H}-15\right), 3.22$ 
(dd, $J=9.5,8.5 \mathrm{~Hz}, 1 \mathrm{H} ; \mathrm{H}-4), 3.34-3.41$ (m, 1H; H-5), 3.50 (dd, $J=9.4,8.5 \mathrm{~Hz}, 1 \mathrm{H} ; \mathrm{H}-3$ ), 3.57 (dd, $J=9.4,5.6 \mathrm{~Hz}, 1 \mathrm{H} ; \mathrm{H}-2), 3.61$ $\left(\mathrm{dd}, J=11.5,5.6 \mathrm{~Hz}, 1 \mathrm{H} ; \mathrm{H}^{\mathrm{A}}-6\right), 3.77(\mathrm{dd}, J=11.5,2.3 \mathrm{~Hz}, 1 \mathrm{H}$; $\mathrm{H}^{\mathrm{B}}-6$ ), 3.86 (ddd, $J=10.3,5.6$ and $\left.3.9 \mathrm{~Hz}, 1 \mathrm{H} ; \mathrm{H}-1\right), 4.32$ $\left(\mathrm{t}, J=7.0 \mathrm{~Hz}, 2 \mathrm{H} ; \mathrm{CH}_{2}-12\right), 7.67$ (s, 1H; H-13); ${ }^{13} \mathrm{C}-\mathrm{NMR}$ (100 MHz, CD 3 OD) $\delta 7.3$ (C-15), 8.2 (C-16, C-17), 25.3 (C-7), 26.4 (C-8), 27.4 (C-10), 29.8 (C-9), 31.2 (C-11), 51.2 (C-12), 63.2 (C-6), 72.5 (C-4), 73.1 (C-2), 74.4 (C-5), 75.3 (C-3), 77.2 (C-1), 121.8 (C-13), 151.4 (C-14); HRMS (ESI) $m / z 356.2200\left([\mathrm{M}+\mathrm{H}]^{+}\right.$, calcd for $\left.\mathrm{C}_{17} \mathrm{H}_{30} \mathrm{~N}_{3} \mathrm{O}_{5}: 356.2180\right)$.

\section{Compound 3}

To a solution of heptakis(2,6-di-O-propargyl)cyclo maltoheptaose 12 (13 mg, $0.0078 \mathrm{mmol}$ ) and 9 ( $55 \mathrm{mg}, 0.1202 \mathrm{mmol}, 15.4$ eq.) in DMF $(1.2 \mathrm{~mL})$ in a microwave vial was added a yellow suspension of $\mathrm{CuSO}_{4} \cdot 5 \mathrm{H}_{2} \mathrm{O}(3 \mathrm{mg}, 0.0120 \mathrm{mmol}, 1.5 \mathrm{eq}$.) and sodium ascorbate ( $5 \mathrm{mg}, 0.0252 \mathrm{mmol}, 3.2 \mathrm{eq}$.) in water $(0.3 \mathrm{~mL})$. The resulting suspension was stirred and heated under microwave irradiation at $80{ }^{\circ} \mathrm{C}$ for $30 \mathrm{~min}$. The reaction mixture was diluted with water and extracted with EtOAc $(3 \times 10 \mathrm{~mL})$. The combined organic extracts were washed with water, dried over $\mathrm{Na}_{2} \mathrm{SO}_{4}$, filtered and concentrated under reduced pressure. The residue was diluted with a mixture of $\mathrm{MeCN} / \mathrm{H}_{2} \mathrm{O} / \mathrm{NH}_{4} \mathrm{OH}(15: 0.5: 0.5)$ and filtered through a pad of silica gel, using the same mixture as the eluent. Copper salts precipitated as a blue powder and remained at the top of the silica gel pad. The filtrate was concentrated under reduced pressure and the crude residue was purified by flash column chromatography $\left(\mathrm{CH}_{2} \mathrm{Cl}_{2} / \mathrm{MeOH}\right.$, $98: 2$ to $95: 5)$ to afford $3(52 \mathrm{mg}, 83 \%)$ as a pale yellow oil.

$R_{\mathrm{f}} 0.34\left(\mathrm{CH}_{2} \mathrm{Cl}_{2} / \mathrm{MeOH}, 96: 4\right) ;[\alpha]_{\mathrm{D}}^{20}+57\left(c\right.$ 2.0, $\left.\mathrm{CHCl}_{3}\right) ; \mathrm{IR}$ (neat) $1744,3424 \mathrm{~cm}^{-1} ;{ }^{1} \mathrm{H}-\mathrm{NMR}\left(400 \mathrm{MHz}, \mathrm{CDCl}_{3}\right) \delta 1.19-1.51$ $\left(\mathrm{m}, 98 \mathrm{H} ; \mathrm{H}^{\mathrm{A}}-7, \mathrm{CH}_{2}-8, \mathrm{CH}_{2}-9\right.$ and $\left.\mathrm{CH}_{2}-10\right), 1.68-1.81(\mathrm{~m}, 14 \mathrm{H}$; $\mathrm{H}^{\mathrm{B}}-7$ ), 1.81-1.95 (m, 28H; $\mathrm{CH}_{2}-11$ ), 1.95-2.07 (several s, $168 \mathrm{H}$; $\left.56 \times \mathrm{C}(\mathrm{O}) \mathrm{CH}_{3}\right), 3.28-3.54\left(\mathrm{~m}, 14 \mathrm{H} ; \mathrm{H}-2^{\prime}\right.$ and $\left.\mathrm{H}-4^{\prime}\right), 3.56-3.73$ (m, 7H; H-5'), 3.73-3.83 (m, 14H; H-5), 3.91 (dd, J = 8.9 Hz, 7H; $\mathrm{H}-3^{\prime}$ ), 4.04 (dt, $\left.J=12.1,2.3 \mathrm{~Hz}, 14 \mathrm{H} ; \mathrm{H}^{\mathrm{A}}-6\right), 4.08-4.15(\mathrm{~m}, 14 \mathrm{H}$; $\mathrm{H}-1$ ), 4.21 (dd, $\left.J=12.1,4.9 \mathrm{~Hz}, 14 \mathrm{H} ; \mathrm{H}^{\mathrm{B}}-6\right), 4.30$ (t, $J=7.3 \mathrm{~Hz}$, $\left.14 \mathrm{H} ; \mathrm{CH}_{2}-12\right), 4.35\left(\mathrm{t}, J=7.3 \mathrm{~Hz}, 14 \mathrm{H} ; \mathrm{CH}_{2}-12\right), 4.42-4.68$ $\left(\mathrm{m}, 14 \mathrm{H} ; \mathrm{CH}_{2}-6^{\prime}\right)$, 4.69-4.81 (m, 7H; H-1'), 4.84-5.02 (m, $14 \mathrm{H}$; $\mathrm{CH}_{2}-7^{\prime}$ or $\mathrm{CH}_{2}-10^{\prime}$ ), 4.95 (dd, $J=9.1 \mathrm{~Hz}, 14 \mathrm{H} ; \mathrm{H}-4$ ), 5.02 (dd, $J=9.5,5.7 \mathrm{~Hz}, 14 \mathrm{H} ; \mathrm{H}-2), 5.23-3.31$ (m, 28H; H-3 and $\mathrm{CH}_{2}-7^{\prime}$ or $\left.\mathrm{CH}_{2}-10^{\prime}\right)$, 7.54-7.80 (m, $14 \mathrm{H} ; \mathrm{H}-9^{\prime}$ and $\left.\mathrm{H}-12{ }^{\prime}\right)$; ${ }^{13} \mathrm{C}-\mathrm{NMR}$ $\left(100 \mathrm{MHz}, \mathrm{CDCl}_{3}\right) \delta 20.7,20.78,20.82\left(\mathrm{CH}_{3}\right), 25.0,25.3$, 26.7, 28.8 (C-7, C-8, C-9, C-10), 30.4 (C-11), 50.26, 50.35 (C-12), 53.5 (C-7' or C-10'), 62.4 (C-6), 64.9, $65.2\left(\mathrm{C}-6^{\prime}\right.$ and $\mathrm{C}-7^{\prime}$ or $\left.\mathrm{C}-10^{\prime}\right)$, $68.67\left(\mathrm{C}-5\right.$ and $\left.\mathrm{C}-5^{\prime}\right), 68.99$ (C-4), $70.52,70.55$ (C-2 and C-3), 72.6 (C-1), $73.4\left(\mathrm{C}-3^{\prime}\right), 79.1\left(\mathrm{C}-2^{\prime}\right), 83.0\left(\mathrm{C}-4^{\prime}\right), 101.7\left(\mathrm{C}-1^{\prime}\right), 122.9$, 123.6 (C-9', $\left.\mathrm{C}-12^{\prime}\right), 144.1,144.7\left({\mathrm{C}-8^{\prime}}^{\prime}, \mathrm{C}-11^{\prime}\right), 169.6,169.7,170.2$, $170.7\left(\mathrm{C}(\mathrm{O}) \mathrm{CH}_{3}\right)$; HRMS (ESI) $m / z 2713.4838\left([\mathrm{M}+3 \mathrm{Na}]^{3+}\right.$, calcd for $\mathrm{C}_{364} \mathrm{H}_{532} \mathrm{~N}_{42} \mathrm{O}_{161} \mathrm{Na}_{3}$ : 2713.4844).

\section{Compound $2 \mathrm{~b}$}

To a solution of $3(50 \mathrm{mg}, 0.0062 \mathrm{mmol})$ in a mixture of $\mathrm{MeOH}$ $(1 \mathrm{~mL})$ and water $(1 \mathrm{~mL})$ was added Amberlite IRA400 $\left(\mathrm{OH}^{-}\right)$ resin $(2.20 \mathrm{~g})$. The mixture was stirred using the rotavapor at $\mathrm{rt}$ for $20 \mathrm{~h}$. The resin was then filtered, rinsed with $\mathrm{MeOH}$ and water, and the filtrate was concentrated under reduced pressure. The solvents were evaporated under reduced pressure to afford $\mathbf{2 b}$ (33 $\mathrm{mg}, 93 \%)$ as a pale yellow oil.

$[\alpha]_{\mathrm{D}}^{20}+80\left(c\right.$ 1.0, $\left.\mathrm{H}_{2} \mathrm{O}\right)$; IR (neat) $3369 \mathrm{~cm}^{-1}$; ${ }^{1} \mathrm{H}-\mathrm{NMR}(300$ $\left.\mathrm{MHz}, \mathrm{D}_{2} \mathrm{O}\right) \delta$ 1.10-1.94 (m, $140 \mathrm{H} ; \mathrm{CH}_{2}-7, \mathrm{CH}_{2}-8, \mathrm{CH}_{2}-9, \mathrm{CH}_{2}-10$ and $\mathrm{CH}_{2}-11$ ), 3.30-3.99 (m, 140H; H-1, H-2, H-2' $, \mathrm{H}-3, \mathrm{H}-3^{\prime}, \mathrm{H}-4$, $\mathrm{H}-4^{\prime}, \mathrm{H}-5, \mathrm{H}-5^{\prime}, \mathrm{CH}_{2}-6$ and $\left.\mathrm{CH}_{2}-6^{\prime}\right), 4.15-4.65\left(\mathrm{~m}, 42 \mathrm{H} ; \mathrm{CH}_{2}-7^{\prime}\right.$ or $\left.\mathrm{CH}_{2}-10^{\prime}, \mathrm{CH}_{2}-12\right)$, 4.80-5.04 (m, 21H; H-1', $\mathrm{CH}_{2}-7^{\prime}$ or $\mathrm{CH}_{2}-10^{\prime}$ ), 7.92 (br s, 7H; H-9' or $\mathrm{H}-12^{\prime}$ ), 8.09 (s, 7H; $\mathrm{H}-9^{\prime}$ or $\mathrm{H}-12^{\prime}$ ); ${ }^{13} \mathrm{C}-\mathrm{NMR}\left(75.5 \mathrm{MHz}, \mathrm{D}_{2} \mathrm{O}\right) \delta 23.4,23.5,24.4,24.5,25.55$, 25.62, 27.8, 27.9, 29.5, 29.6 (C-7, C-8, C-9, C-10, C-11), 50.2, 50.4 (C-12), 61.1, 61.2 (C-6), 63.4, 64.5 (C-7', C-10'), 68.6 (C-6'), $70.32,70.35$ (C-4, C-5'), 71.4 (C-2), 72.4 (C-5), 72.8 (C-3'), 73.5 (C-3), 75.7 (C-1), $79.4\left(\mathrm{C}-2^{\prime}\right), 81.9\left(\mathrm{C}^{\prime} 4^{\prime}\right), 100.4\left(\mathrm{C}-1^{\prime}\right), 124.6,125.2$ (C-9', C-12'), 143.4, 143.9 (C-8', C-11'); HRMS (ESI) $m / z$ 1430.4807 $\left([\mathrm{M}+4 \mathrm{H}]^{4+}\right.$, calcd for $\left.\mathrm{C}_{252} \mathrm{H}_{424} \mathrm{~N}_{42} \mathrm{O}_{105}: 1430.4799\right)$.

\section{Compound $2 \mathrm{a}$}

A mixture of 13 (37.3 mg, $0.018 \mathrm{mmol}), \mathbf{4 b}(68 \mathrm{mg}, 0.235 \mathrm{mmol})$, $\mathrm{CuSO}_{4} \cdot 5 \mathrm{H}_{2} \mathrm{O}(1.3 \mathrm{mg}, 52 \mu \mathrm{mol})$ and sodium ascorbate $(3.5 \mathrm{mg}$, $0.018 \mathrm{mmol}$ ) in $\mathrm{CH}_{2} \mathrm{Cl}_{2} / \mathrm{H}_{2} \mathrm{O} / \mathrm{DMSO}$ (0.6: $0.4: 0.4 \mathrm{~mL}$ ) was stirred at $30{ }^{\circ} \mathrm{C}$ under argon for 3 days. $\mathrm{MeOH}(10 \mathrm{~mL})$ was added. The orange-brown precipitate was filtered and washed with $\mathrm{MeOH}$ and acetone. Two successive gel permeation chromatographies (Sephadex G-25, $\mathrm{H}_{2} \mathrm{O}$ ) followed by filtration over a QuadraSil $^{\mathrm{TM}}$ Mercaptopropyl column gave 2a (33 mg, 34\%) as an orange-brown glassy product. IR (neat) 3340 (br, OH), 1738 $(\mathrm{C}=\mathrm{O}) \mathrm{cm}^{-1}$; UV/vis $\left(\mathrm{H}_{2} \mathrm{O} / \mathrm{DMSO} 10: 0.2\right) \lambda_{\max }(\varepsilon)=235$ (179900), 273 (sh, 66 400), 337 (sh, 31700$) \mathrm{nm} ;{ }^{1} \mathrm{H}$ NMR $(400 \mathrm{MHz}$, $\left.\mathrm{D}_{2} \mathrm{O} / \mathrm{DMSO}_{6} \mathrm{~d}_{6} 4: 1\right) \delta 7.84(\mathrm{~s}, 12 \mathrm{H}), 4.80(\mathrm{~m}, 36 \mathrm{H}), 4.42-4.02$ $(\mathrm{m}, 60 \mathrm{H}), 3.66(\mathrm{~m}, 12 \mathrm{H}), 3.17(\mathrm{~m}, 12 \mathrm{H}), 3.01(\mathrm{~m}, 12 \mathrm{H}), 2.62$ (m, 24H), 2.05-1.57 (m, 60H), 1.54-1.03 (m, 84H); ${ }^{13} \mathrm{C}$ NMR (100 MHz, DMSO-d $\left.{ }_{6}\right) \delta 163.2,146.2,145.4,141.2,122.5,75.5$, 74.2, 73.8, 71.9, 71.3, 69.2, 67.0, 61.9, 49.9, 46.0, 30.1, 28.8, 28.2, 26.4, 25.4, 24.3, 21.9; ES-TOF-MS $m / z 1889.04\left([\mathrm{M}+3 \mathrm{Na}]^{3+}\right.$, calcd for $\mathrm{C}_{282} \mathrm{H}_{360} \mathrm{~N}_{36} \mathrm{O}_{84} \mathrm{Na}_{3}$ : 1889.02).

\section{Inhibition studies with commercial enzymes}

Inhibition constant $\left(K_{\mathrm{i}}\right)$ values were determined by spectrophotometrically measuring the residual hydrolytic activities of the glycosidases against the respective $p$-nitrophenyl $\alpha$ - or $\beta$-D-glycopyranoside, $o$-nitrophenyl $\beta$-D-galactopyranoside (for $\beta$-galactosidases) in the presence of the $C$-glycosides. Each assay was performed in phosphate buffer or phosphate-citrate buffer (for $\alpha$ - or $\beta$ - mannosidase and amyloglucosidase) at the optimal $\mathrm{pH}$ of each enzyme. The reactions were initiated by addition of the enzyme to a solution of the substrate in the absence or presence of various concentrations of inhibitor. The mixture was incubated for $10-30 \mathrm{~min}$ at $37^{\circ} \mathrm{C}$ or $55^{\circ} \mathrm{C}$ (for amyloglucosidase) and the reaction was quenched by addition of $1 \mathrm{M} \mathrm{Na}_{2} \mathrm{CO}_{3}$. Reaction times were approximated to obtain $10-20 \%$ conversion of the substrate in order to achieve linear rates. The absorbance of the resulting mixture was determined at $405 \mathrm{~nm}$. Approximate values of $K_{\mathrm{i}}$ were determined using a fixed concentration of substrate (around the $K_{\mathrm{m}}$ value for different glycosidases) and 
various concentrations of inhibitor. Full $K_{\mathrm{i}}$ and enzyme inhibition modes were determined from Dixon plots.

\section{Acknowledgements}

The authors are grateful to financial support from the Institut Universitaire de France (IUF), the CNRS (UMR 7509), the University of Strasbourg and the International Centre for Frontier Research in Chemistry (icFRC). FS thanks the French Department of Research for a doctoral fellowship. The Spanish Ministerio de Economía y Competitividad (MINECO, contract numbers SAF2013-44021-R) and cofinancing from the European Regional Development Funds (FEDER and FSE) are also thanked.

\section{Notes and references}

1 P. Compain, C. Decroocq, J. Iehl, M. Holler, D. Hazelard, T. Mena Barragán, C. Ortiz Mellet and J.-F. Nierengarten, Angew. Chem., Int. Ed., 2010, 49, 5753-5756.

2 C. Decroocq, D. Rodríguez-Lucena, V. Russo, T. Mena Barragán, C. Ortiz Mellet and P. Compain, Chem. - Eur. J., 2011, 17, 13825-13831.

3 M. L. Lepage, J. P. Schneider, A. Bodlenner, A. Meli, F. De Riccardis, M. Schmitt, C. Tarnus, N.-T. Nguyen-Huynh, Y.-N. Francois, E. Leize-Wagner, C. Birck, A. Cousido-Siah, A. Podjarny, I. Izzo and P. Compain, Chem. - Eur. J., 2016, 15, 5151-5155.

4 For reviews, see: (a) P. Compain and A. Bodlenner, ChemBioChem, 2014, 15, 1239-1251; (b) S. G. Gouin, Chem. - Eur. J., 2014, 20, 11616-11628; (c) R. Zelli, J.-F. Longevial, P. Dumy and A. Marra, New J. Chem., 2015, 39, 5050-5074; (d) N. Kanfar, E. Bartolami, R. Zelli, A. Marra, J.-Y. Winum and P. Dumy, Org. Biomol. Chem., 2015, 13, 9894-9906.

5 J. M. Rini, Annu. Rev. Biophys. Biomol. Struct., 1995, 24, 551-577.

6 Iminosugars: from Synthesis to Therapeutic Applications, ed.

P. Compain and O. R. Martin, Wiley \& Sons, Chichester, 2007.

7 Iminosugars as Glycosidase Inhibitors: Nojirimycin and Beyond, ed. A. E. Stütz, Wiley-VCH, New York, 1999.

8 (a) D. L. Zechel and S. G. Withers, Acc. Chem. Res., 2000, 33, 11-18; (b) T. D. Heightman and A. T. Vasella, Angew. Chem., Int. Ed., 1999, 38, 750-770; (c) C. S. Rye and S. G. Withers, Curr. Opin. Chem. Biol., 2000, 4, 573-580.

9 For recent reviews, see: (a) M. Lahmann, Top. Curr. Chem., 2009, 288, 17-65; (b) D. Deniaud, K. Julienne and S. G. Gouin, Org. Biomol. Chem., 2011, 9, 966-979; (c) A. Imberty, Y. Chabre and R. Roy, Chem. - Eur. J., 2008, 14, 7490-7499; (d) Y. M. Chabre and R. Roy, Adv. Carbohydr. Chem. Biochem., 2010, 63, 165-393; (e) M. Hartmann and T. K. Lindhorst, Eur. J. Org. Chem., 2011, 3583-3609; $(f)$ N. Jayaraman, Chem. Soc. Rev., 2009, 38, 3463-3483; ( $g$ ) A. Martínez, C. Ortiz Mellet and J. M. García Fernández, Chem. Soc. Rev., 2013, 42, 4746-4773; (h) Y. M. Chabre and R. Roy, Chem. Soc. Rev., 2013, 42, 4657-4708; (i) S. Cecioni, A. Imberty and S. Vidal, Chem. Rev., 2015, 115, 525-561.
10 (a) M. Mammen, S.-K. Choi and G. M. Withesides, Angew. Chem., Int. Ed., 1998, 37, 2754-2794; (b) J. E. Gestwicki, C. W. Cairo, L. E. Strong, K. A. Oetjen and L. L. Kiessling, J. Am. Chem. Soc., 2002, 124, 14922-14933; (c) L. Kiessling, J. E. Gestwicki and L. E. Strong, Curr. Opin. Chem. Biol., 2000, 4, 696-703; (d) M. I. Page and W. P. Jencks, Proc. Natl. Acad. Sci. U. S. A., 1971, 68, 1678-1683; (e) V. Wittmann and R. J. Pieters, Chem. Soc. Rev., 2013, 42, 4492-4503; $(f)$ R. J. Pieters, Org. Biomol. Chem., 2009, 7, 2013-2025.

11 Y. Brissonnet, C. Ortiz Mellet, S. Morandat, M. I. GarcíaMoreno, D. Deniaud, S. E. Matthews, S. Vidal, S. Sesták, K. El Kirat and S. G. Gouin, J. Am. Chem. Soc., 2013, 135, 18427-18435.

12 (a) C. Decroocq, A. Joosten, R. Sergent, T. Mena Barragán, C. Ortiz Mellet and P. Compain, ChemBioChem, 2013, 14, 2038-2049; (b) This side-reaction has been previously observed for the CuAAC reaction of 1-pentyne with azidearmed iminosugar substrates (see ref. 12a).

13 E. Moreno-Clavijo, A. T. Carmona, A. J. Moreno-Vargas, L. Molina, D. W. Wright, G. J. Davies and I. Robina, Eur. J. Org. Chem., 2013, 7328-7336.

14 R. Rísquez-Cuadro, J. M. García Fernández, J.-F. Nierengarten and C. Ortiz Mellet, Chem. - Eur. J., 2013, 19, 16791-16803.

15 For recent reviews, see: $(a)$ B. P. Rempel and S. G. Withers, Glycobiology, 2008, 18, 570-586; (b) T. Kajimoto and M. Node, Curr. Top. Med. Chem., 2009, 9, 13-33; (c) N. Asano, R. J. Nash, R. J. Molyneux and G. W. J. Fleet, Tetrahedron: Asymmetry, 2000, 11, 1645-1680; (d) T. Kajimoto and M. Node, Curr. Top. Med. Chem., 2009, 9, 539; (e) A. E. Stütz and T. M. Wrodnigg, Adv. Carbohydr. Chem. Biochem., 2011, 66, 187-298; $(f)$ U. Ghani, Eur. J. Med. Chem., 2015, 103, 133-162; (g) A. Singha, N. Mhlongoa and M. E. S. Soliman, Anti-Cancer Agents Med. Chem., 2015, 15, 933-946; (h) N. F. Brás, N. M. F. S. A. Cerqueria, M. J. Ramos and P. A. Fernades, Expert Opin. Ther. Pat., 2014, 24, 857-874; (i) E. M. SánchezFernández, J. M. García Fernández and C. Ortiz Mellet, Chem. Commun., 2016, 52, 5497-5515.

16 (a) C. Decroocq, D. Rodríguez-Lucena, K. Ikeda, N. Asano and P. Compain, ChemBioChem, 2012, 13, 661-664; (b) P. Compain, C. Decroocq, A. Joosten, J. de Sousa, D. Rodriguez-Lucena, T. D. Butters, J. Bertrand, R. Clément, C. Boinot, F. Becq and C. Norez, ChemBioChem, 2013, 14, 2050-2058; (c) A. Joosten, C. Decroocq, J. de Sousa, J. Schneider, E. Etamé, A. Bodlenner, T. D. Butters and P. Compain, ChemBioChem, 2014, 15, 309-319.

17 Recent reports on $\mathrm{sp}^{2}$-iminosugars: (a) T. Mena-Barragán, A. Narita, D. Matias, G. Tiscornia, E. Nanba, K. Ohno, Y. Suzuki, K. Higaki, J. M. Garcia Fernández and C. Ortiz Mellet, Angew. Chem., Int. Ed., 2015, 54, 11696; (b) M. De la Mata, D. Cotán, M. Oropesa-Ávila, J. Garrido-Maraver, M. D. Cordero, M. Villanueva Paz, A. Delgado Pavón, E. Alcocer-Gómez, I. de Lavera, P. Ybot-González, A. P. Zaderenko, C. Ortiz Mellet, J. M. García Fernández and J. A Sánchez Alcázar, Sci. Rep., 2015, 5, 10903; (c) E. M. Sánchez-Fernández, V. Gómez-Perez, R. García-Hernández, J. M. García Fernández, G. B. Plata, J. M. Padrón, C. Ortiz Mellet, S. Castanys-Cuello and 
F. Gamarro-Conde, $R S C A d v ., 2015,5,21812$; (d) E. M. Sánchez-Fernández, R. Gonçalves-Pereira, R. RísquezCuadro, G. B. Plata, J. M. Padrón, J. M. García Fernández and C. Ortiz Mellet, Carbohydr. Res., 2016, 429, 113-122.

18 Glycosidase inhibitors based on nanodiamond-grafted $O$-glycosides have been described very recently in the literature: A. Siriwardena, M. Khanal, A. Barras, O. Bande, T. Mena-Barragán, C. Ortiz Mellet, J. M. Garcia Fernández, R. Boukherroub and S. Szunerits, RSC Adv., 2015, 5, 100568.

19 A. Hosomi, Y. Sakata and H. Sakurai, Carbohydr. Res., 1987, 171, 223-232.

20 (a) G. J. McGarvey, C. A. LeClair and B. A. Schmidtmann, Org. Lett., 2008, 10, 4727-4730; (b) E. Brenna, C. Fuganti, P. Grasselli, S. Serra and S. Zambotti, Chem. - Eur. J., 2002, 8, 1872-1878.

21 T. Šmejkal and B. Breit, Angew. Chem., Int. Ed., 2008, 47, 311-315.

22 (a) B. Schmidt, Eur. J. Org. Chem., 2004, 1865-1880; (b) S. H. Hong, M. W. Day and R. H. Grubbs, J. Am. Chem. Soc., 2004, 126, 7414-7415; (c) D. V. McGrath and R. H. Grubbs, Organometallics, 1994, 13, 224-235.
23 (a) S. H. Hong, D. P. Sanders, C. W. Lee and R. H. Grubbs, J. Am. Chem. Soc., 2005, 127, 17160-17161; (b) G. Csjernyik, A. H. Éll, L. Fadini, B. Pugin and J.-E. Bäckvall, J. Org. Chem., 2002, 67, 1657-1662.

24 F. Ortega-Caballero, J. J. Giménez-Martínez and A. VargasBerenguel, Org. Lett., 2003, 5, 2389-2392.

25 J. Iehl and J.-F. Nierengarten, Chem. - Eur. J., 2009, 15, 7306-7309.

26 J.-F. Nierengarten, J. Iehl, V. Oerthel, M. Holler, B. M. Illescas, A. Muñoz, N. Martín, J. Rojo, M. Sánchez-Navarro, S. Cecioni, S. Vidal, K. Buffet, M. Durka and S. P. Vincent, Chem. Commun., 2010, 46, 3860-3862.

27 The residual copper traces in compound $2 \mathbf{a}$ are expected to have no impact on $\alpha$-mannosidase activity for the incubation time used as shown in a previous model study by Marra et al. using large concentrations of $\mathrm{CuSO}_{4}$ (up to $200 \mu \mathrm{M}$ ), see: A. Marra, R. Zelli, G. D’Orazio, B. La Ferla and A. Dondoni, Tetrahedron, 2014, 70, 9387-9393.

28 J. Lee and M. Paetzel, Acta Crystallogr., 2011, F67, 188-192.

29 E. M. S. Harris, A. E. Aleshin, L. M. Firsov and R. B. Honzatko, Biochemistry, 1993, 32, 1618-1626. 